\title{
PERTANGGUNGJAWABAN HUKUM PRAKTIK TUKANG GIGI YANG MELEBIHI WEWENANGNYA
}

\author{
Devi Dharmawan, Ivonne Jonathan \\ Universitas Hang Tuah, Jalan Arief Rachman Hakim No.150, Keputih, Sukolilo, Keputih, Sukolilo, Kota \\ SBY, Jawa Timur 60111
}

\begin{abstract}
Background: The public's lack of understanding of the different professions of dental artisans, dental technicians, and dentists has an impact on the practice that exceeds the authority carried out for years without any legal consequences borne by dental artisans. Although the regulations concerning work that can be done by dental artisans have been clearly explained in Permenkes No. 39 of 2014 this is still violated by dental artisans. In this case the people are victims because of ignorance and high local wisdom in certain areas. Method: This study uses a type of normative juridical legal research. Normative legal research is research that focuses its study by viewing law as a whole system rule which includes a set of principles, norms and rules of law, both written and unwritten. Results: Giving the right to claim compensation to the patient is an effort to provide protection for each patient for a result that arises both physically and non-physically due to a mistake or negligence by health personnel. Conclusion: Dental workers can be charged with the Criminal Code article 359, 360, 361, namely whoever is due to his mistake (negligence) causes other people to be injured, severely disabled, or even die. In addition, the Consumer Protection Act No.8 of 1999 Article 4 of the Consumer Protection Law has the right to comfort, security and safety in consuming goods and / or services can be used.
\end{abstract}

Keywords: Dental Artisan Practice, Legal Liability, Authority

\section{PENDAHULUAN}

Profesi Tukang Gigi telah banyak dikenal oleh masyarakat Indonesia, bahkan sebelum dunia Kedokteran Gigi berdiri di Indonesia. Sejak awal Januari 2013, jumlah Profesi Tukang Gigi yang terdata sebanyak \pm 75.000. Masih banyaknya praktek tukang gigi menandakan bahwa masyarakat kita meminati jasa Tukang Gigi. Meskipun tidak memiliki standar keamanan medis seperti Dokter Gigi, namun biaya yang dikeluarkan untuk membayar jasa tukang gigi relatif terjangkau. Maka tak jarang jika Tukang Gigi masih melekat di hati masyarakat Indonesia. Pelayanan Tukang
Gigi bermacam-macam, mulai dari menambal, mencabut, melakukan implan gigi, pasang kawat gigi, membuat dan memasang gigi tiruan. Praktek tersebut hampir menyamai kompetensi seorang dokter gigi. Dibekali dengan pendidikan secukupnya, bahkan yang sekedar autodidak, seorang sudah bisa menjadi Tukang Gigi. Para tukang gigi ini bertindak layaknya profesional. Mereka menyediakan layanan orthodonti seperti pemasangan behel dan veneer. Harga murah menjadi andalan para tukang gigi untuk menarik pasien. Dari sudut pandang praktisi medis, tindakan Tukang Gigi memang dianggap tak memenuhi kaidah 
tindakan medis semestinya. Persoalan ini pula yang menjadi perhatian pemerintah, sehingga mencoba membuat aturan mainnya terhadap penyelengaraan kegiatan praktik Tukang Gigi. Sayangnya, meski telah diberi batasan untuk bisa berpraktik membuat dan memasang gigi akrilik lepasan, tapi di lapangan tak menjamin praktik di luar kewenangan tukang gigi berjalan sesuai aturan. Pada akhirnya, diserahkan ke masyarakat agar paham dan sadar saat memilih perawatan ortodonti. Perawatan gigi dan mulut yang dilakukan bukan oleh seorang profesional berisiko kesehatan pada pasien. Sayangnya, tak semua masyarakat memperhatikan persoalan ini. Permintaan jasa perawatan gigi dengan harga murah masih menjadi pilihan masyarakat. drg. Widya Apsari, Sp. PM, spesialis penyakit mulut memberikan penjelasan risiko perawatan ortodonti yang dilakukan di tukang gigi. Dari pemakaian behel misalnya, para tukang gigi tak mengetahui hitungan pasti kekuatan kawat gigi yang dipasang. Akibatnya, gigi dapat melenceng, bahkan lepas, dan membuat bentuk rahang jadi tak proporsional. Lalu pada pemasangan veneer dengan pengalaman yang tidak tepat, atau langsung menempel akrilik tanpa melihat masalah gigi lain, seperti ompong atau karang gigi. Tindakan tersebut bisa mengakibatkan pembengkakan gusi dan infeksi menahun. "Tidak tepatnya penanganan dapat terlihat dari bentuk rahang yang miring, terlihat monyong, atau mulutnya seperti tidak bisa menutup," kepada Tirto. Kondisi tersebut diakibatkan karena metode penanganan singkat dan tak berdasar yang dilakukan tukang gigi saat melakukan tindakan. Sedangkan untuk pemasangan behel di dokter gigi terlebih dulu harus melalui rontgen dan mencetak gigi. Tujuannya, untuk menemukan struktur gigi ideal yang ingin dicapai di masa akhir terapi. Di tukang gigi, tahapan ini jelas dilompati.

Berdasarkan uraian diatas peneliti tertarik untuk mengetahui bentuk pertanggungjawaban tukang gigi yang memberikan jasa pelayanan kesehatan gigi di luar kewenangan yang telah diatur dalam perundang-undangan berdasarkan hukum positif di Indonesia dari segi pidana, perdata, administrasi, serta hukum kesehatan. Adapun judul penelitian ini adalah "Pertanggungjawaban hukum praktik tukang gigi dalam hukum positif di Indonesia."

\section{METODE PENELITIAN}

Penelitian ini menggunakan tipe penelitian hukum yuridis normatif. Penelitian hukum normatif adalah penelitian yang memfokuskan kajiannya dengan memandang hukum sebagai suatu kaidah sistem utuh yang meliputi seperangkat asas, norma dan aturan hukum, baik yang tertulis maupun tidak tertulis.

Pendekatan dalam penelitian hukum ini berfungsi sebagai sudut pandang dan kerangka berpikir seorang peneliti dalam melakukan analisa. Berbagai pendekatan yang digunakan dalam penelitian ini yaitu :

a. Pendekatan perundang-undangan
(Statute Approach)
Pendekatan penelitian ini dilakukan dengan menganalisa berbagai peraturan perundang - undangan yang terkait dengan isu hukum. Penulis menggunakan peraturan perundang-undangan dan norma-norma hukum yang berhubungan dengan kewenangan tukang gigi sebagai dasar dalam melakukan analisis. 
b. Pendekatan konseptual (Conseptual Approach)

Pendekatan ini dilakukan dengan menelaah pandangan - pandangan, kaidah-kaidah dan doktrin - doktrin yang berkembang di dalam ilmu hukum. Penulis menggunakan pendekatan ini untuk mengkaji terhadap teori - teori, asas-asas, definisi tertentu yang dipakai sebagai landasan pengertian dan landasan dalam pelaksanaan yang berkaitan dengan pertanggungjawaban hukum tukang gigi apabila melakukan praktik melebihi wewenangnya.

\section{Bahan Hukum}

Jenis bahan hukum yang digunakan dalam penelitian ini adalah bahan hukum primer dan sekunder. Bahan hukum primer merupakan data yang diperoleh langsung dari narasumber atau langsung dari sumber pertama di lapangan melalui penelitian. Bahan sekunder merupakan data yang diperoleh dari dokumen-dokumen resmi, buku-buku dan hasil penelitian. Bahan hukum adalah segala sesuatu yang dapat dipakai atau diperlukan untuk tujuan menganalisis hukum yang berlaku. Bahan hukum yang dikaji dan yang dianalisis dalam penelitian hukum normatif terdiri dari :

\section{a. Bahan Hukum Primer}

Bahan hukum primer adalah bahan hukum yang memiliki kekuatan mengikat yang didapatkan dari peraturan perundang - undangan. Peraturan perundangundangan yang digunakan dalam proposal tesis ini meliputi :

1. Undang-Undang Dasar Negara Republik Indonesia Tahun 1945.

2. Undang-Undang Nomor 36 Tahun 2009 Tentang Kesehatan

3. Undang-Undang Nomor 29 tahun 2004 tentang Praktik Kedokteran
4. Peraturan Menteri Kesehatan Nomor 39 Tahun 2014 tentang Pembinaan, Pengawasan dan Perizinan, Pekerjaan Tukang Gigi.

5. Peraturan Menteri Kesehatan Nomor 1872 Tahun 2011 tentang Pencabutan Peraturan Menteri Kesehatan Nomor 339/MENKES/PER/V/1989 tentang Pekerjaan Tukang Gigi

6. Peraturan Menteri Kesehatan Nomor 339 Tahun 1989 tentang Pekerjaan Tukang Gigi

\section{b. Bahan Hukum Sekunder}

Bahan hukum sekunder adalah bahan hukum yang dapat memberikan informasi mengenai bahan hukum primer seperti teori hukum dan karya dari kalangan hukum lainnya. Bahan hukum sekunder dalam proposal tesis berjudul pertanggungjawabanhukum praktik tukang gigi dalam hukum positif di Indonesia ini meliputi karya - karya ilmiah, serta buku - buku yang berhubungan dengan penelitian normatif ini.

\section{HASIL PENELITIAN}

Pemasangan kawat gigi pada praktek yang terjadi di masyarakat bukan hanya dilakukan oleh dokter gigi, tetapi juga oleh Tukang Gigi. Keberadaan Tukang Gigi sebagai orang yang dapat membuka praktek membuat dan memasang gigi tiruan lepasan diatur di dalam Permenkes No.39 tahun 2014 tentang Pembinaan, Pengawasan dan Perizinan, Pekerjaan Tukang Gigi. Dalam Permenkes No.39 tahun 2014 tentang Pembinaan, Pengawasan dan Perizinan, Pekerjaan Tukang Gigi pada Pasal 1 angka (1) disebutkan definisi Tukang gigi adalah setiap orang yang mempunyai kemampuan membuat dan memasang gigi 
tiruan lepasan. Selain itu juga di dalamPermenkes Nomor 339 /MENKES/PER/V/1989 tentang Pekerjaan Tukang Gigi disebutkan bahwa: Tukang gigi adalah mereka yang melakukan pekerjaan di bidang penyembuhan dan pemulihan kesehatan gigi dan tidak mempunyai pendidikan berdasarkan ilmu pengetahuan kedokteran gigi serta telah mempunyai izin Menteri Kesehatan untuk melakukan pekerjaannya. Diatur pula wewenang seorang tukang gigi meliputi: a. membuat sebagian/seluruh gigi tiruan dari aklirik; dan b. memasang gigi tiruan lepasan. Mengenai legalitas praktik Tukang gigi ini sempat dicabut dengan dikeluarkannya UU No.29 tahun 2004 tentang Praktek Kedokteran serta Peraturan Menteri Kesehatan 1871/MENKES/PER/IX/2011 tentang pencabutan Peraturan Menteri Kesehatan No. 339/MENKES/PER/V/1989 tentang pekerjaan tukang gigi. Pencabutan tersebut berakibat pada tidak diberikannya izin berpraktik maupun memperpanjang izin praktik tukang gigi.

Pada UU No.29 tahun 2004, Pasal 73 ayat (2) berbunyi, "Setiap orang dilarang menggunakan alat, metode atau cara lain dalam memberikan pelayanan kepada masyarakat yang menimbulkan kesan seolah-olah yang bersangkutan adalah dokter atau dokter gigi yang telah memiliki surat tanda registrasi dan/atau surat izin praktik”.'Dalam Pasal 78 disebutkan "Setiap orang yang dengan sengaja menggunakan alat, metode atau cara lain dalam memberikan pelayanan kepada masyarakat yang menimbulkan kesan seolah-olah yang bersangkutan adalah dokter atau dokter gigi yang telah memiliki surat tanda registrasi dokter atau surat tanda registrasi dokter gigi atau surat izin praktik sebagaimana dimaksud dalam Pasal 73 ayat (2) dipidana dengan pidana penjara paling lama 5 (lima) tahun atau denda paling banyak Rp150.000.000,00 (seratus lima puluh juta rupiah). Disini memberikan larangan kepada siapa saja yang bukan berlatar belakang pendidikan dokter atau dokter gigi untuk membuka praktik, termasuk dalam kriteria ini adalah Tukang gigi. Apabila hal ini tetap dilakukan maka, yang bersangkutan dapat dikenakan pidana penjara atau denda. Hal ini kemudian diajukan permohonan pengujian Pasal 73 ke Mahkamah Konstitusi oleh Hamdani Prayoga. MK mengabulkan permohonan pengujian Pasal 73 ayat (2) dan pasal $78 \underline{\mathrm{UU}}$ No. 29 Tahun 2004tentang Praktik Kedokteran. MK menyatakan kedua pasal itu inkonstitusional bersyarat.

Menurut MK, Pasal 73 ayat (2) bertentangan dengan UUD 1945 dan tidak mempunyai kekuatan hukum mengikat sepanjang tidak dimaknai, "Setiap orang dilarang menggunakan alat, metode atau cara lain dalam memberikan pelayanan kepada masyarakat yang menimbulkan kesan seolah-olah yang bersangkutan adalah dokter atau dokter gigi yang telah memiliki surat tanda registrasi dan/atau surat izin praktik, kecuali tukang gigi yang mendapat izin praktik dari Pemerintah". Rumusan awal Pasal 73 ayat (2) berbunyi, "Setiap orang dilarang menggunakan alat, metode atau cara lain dalam memberikan pelayanan kepada masyarakat yang menimbulkan kesan seolah-olah yang bersangkutan adalah dokter atau dokter gigi yang telah memiliki surat tanda registrasi dan/atau surat izin praktik". Membandingkan dua rumusan itu, Putusan MK berarti menambahkan frasa “.....kecuali tukang 
gigi yang mendapat izin praktik dari Pemerintah". Frasa yang sama juga disisipkan MK ke dalam Pasal 78.

Keberadaan tukang gigi dapat menjadi alternatif bagi masyarakat untuk mendapatkan pelayanan kesehatan gigi yang terjangkau. Hal ini didasarkan pemikiran hingga saat ini pemerintah belum dapat menyediakan pelayanan gigi yang terjangkau bagi seluruh masyarakat. Dalam putusan, MK menyatakan dokter gigi dan tukang gigi seharusnya saling bersinergi dan mendukung satu sama lain dalam upaya meningkatkan kesehatan gigi masyarakat. Seyogyanya, profesi tukang gigi dapat dimasukkan dalam satu jenis pelayanan kesehatan tradisional Indonesia yang harus dilindungi negara dalam suatu peraturan tersendiri. Berdasarkan penilaian hukum itu, Mahkamah berpendapat Pasal 73 ayat (2) UU Praktik Kedokteran bertentangan dengan UUD 1945 secara bersyarat, bertentangan dengan konstitusi jika larangan dalam pasal itu diberlakukan terhadap tukang gigi yang telah memiliki izin dari pemerintah. Terkait Pasal 78, MK menyatakan pasal itu merupakan satu kesatuan yang tidak terpisahkan dari Pasal 73 ayat (2). Pasal 78 UU Praktik Kedokteran harus dinyatakan konstitusional bersyarat, konstitusional sepanjang norma Pasal 78 tidak termasuk tukang gigi yang mendapat izin dari pemerintah.

\section{PEMBAHASAN}

Menyangkut masalah perlindungan hukum terhadap pasien pengguna jasa tukang gigi dalam praktik yang bukan merupakan kompetensinya, maka pasien yang merupakan konsumen, menurut Pasal 4 UU Perlindungan Konsumen mempunyai hak atas kenyamanan, keamanan, dan keselamatan dalam mengkonsumsi barang dan/atau jasa;hak untuk memilih barang dan/atau jasa serta mendapatkan barang dan/atau jasa tersebut sesuai dengan nilai tukar dan kondisi serta jaminan yang dijanjikan;hak atas informasi yang benar, jelas, dan jujur mengenai kondisi dan jaminan barang dan/atau jasa;hak untuk didengar pendapat dan keluhannya atas barang dan/atau jasa yang digunakan;hak untuk mendapatkan advokasi, perlindungan, dan upaya penyelesaian sengketa perlindungan konsumen secara patut;hak untuk mendapat pembinaan dan pendidikan konsumen;hak untuk diperlakukan atau dilayani secara benar dan jujur serta tidak diskriminatif;hak untuk mendapatkan kompensasi, ganti rugi dan/atau penggantian, apabila barang dan/atau jasa yang diterima tidak sesuai dengan perjanjian atau tidak sebagaimana mestinya;hak-hak yang diatur dalam ketentuan peraturan perundang-undangan lainnya.

Sedangkan tukang gigi selaku pelaku usaha mempunyai kewajiban sebagaimana diatur di dalam Pasal 7 UU Perlindungan Konsumen yaitu beritikad baik dalam melakukan kegiatan usahanya;memberikan informasi yang benar, jelas dan jujur mengenai kondisi dan jaminan barang dan/atau jasa serta memberi penjelasan penggunaan, perbaikan dan pemeliharaan;memperlakukan atau melayani konsumen secara benar dan jujur serta tidak diskriminatif;menjamin mutu barang dan/atau jasa yang diproduksi dan/atau diperdagangkan berdasarkan ketentuan standar mutu barang dan/atau jasa yang berlaku;memberi kesempatan kepada konsumen untuk menguji, dan/atau 
mencoba barang dan/atau jasa tertentu serta memberi jaminan dan/atau garansi atas barang yang dibuat dan/atau yang diperdagangkan;memberi kompensasi, ganti rugi dan/atau penggantian atas kerugian akibat penggunaan, pemakaian dan pemanfaatan barang dan/atau jasa yang diperdagangkan;memberi kompensasi, ganti rugi dan/atau penggantian apabila barang dan/atau jasa yang diterima atau dimanfaatkan tidak sesuai dengan perjanjian.

Jika pada saat tukang gigi melakukan pemasangan behel atau pencabutan gigi yang menimbulkan kerugian pada pasien/konsumen, tukang gigi berkewajiban untuk memberikan kompensasi dan ganti rugi kepada pasien. Hal ini sesuai dengan ketentuan yang diatur dalam Pasal 19 ayat (1) UU Perlindungan Konsumen yaitu "Pelaku usaha bertanggung jawab memberikan ganti rugi atas kerusakan, pencemaran, dan/atau kerugian konsumen akibat mengkonsumsi barang dan/atau jasa yang dihasilkan atau diperdagangkan." Ganti rugi tersebut dapat berupa pengembalian uang atau penggantian barang dan/atau jasa yang sejenis atau setara nilainya, atau perawatan kesehatan dan/atau pemberian santunan yang sesuai dengan ketentuan peraturan perundang-undangan yang berlaku (Pasal 19 ayat (2) UU Perlindungan Konsumen). Pemberian ganti rugi dilaksanakan dalam tenggang waktu 7 (tujuh) hari setelah tanggal transaksi (Pasal 19 ayat (3) UU Perlindungan Konsumen. Walaupun tukang gigi tersebut telah memberikan ganti rugi, pemberian ganti rugi tersebut tidak menghapuskan kemungkinan adanya tuntutan pidana berdasarkan pembuktian lebih lanjut mengenai adanya unsur kesalahan (Pasal 19 ayat (4) UU
Perlindungan Konsumen). Akan tetapi, ketentuan ganti rugi tersebut tidak berlaku jika pelaku usaha dapat membuktikan bahwa kesalahan tersebut merupakan kesalahan konsumen.

Selanjutnya apabila praktek tersebut melebihi kompetensinya sebagai tukang gigi sehingga menyebabkan luka atau bahkan kematian karena kealpaan (kesalahannya) dapat didakwa dengan KUHP pasal 359 yaitu barang siapa karena kesalahannya (kealpaannya) menyebabkan orang lain mati, diancam dengan pidana penjara paling lama lima tahun atau pidana kurungan paling lama satu tahun. Sedangkan pada pasal 360 barang siapa karena kesalahannya (kealpaannya) menyebabkan orang lain mendapat luka-luka berat, diancam dengan pidana penjara paling lama lima tahun atau pidana kurungan paling lama satu tahun. Pada pasal (2) barang siapa karena kesalahannya (kealpaannya) menyebabkan orang lain luka-luka sedemikian rupa sehingga timbul penyakit atau halangan menjalankan pekerjaan jabatan atau pencarian selama waktu tertentu, diancam dengan pidana penjara paling lama sembilan bulan atau pidana kurungan paling lama enam bulan atau pidana denda paling tinggi empat ribu lima ratus rupiah. Kemudian pasal 361 jika kejahatan yang diterangkan dalam bab ini dilakukan dalam menjalankan suatu jabatan atau pencarian, maka pidana ditamhah dengan sepertiga dan yang bersalah dapat dicabut haknya untuk menjalankan pencarian dalam mana dilakukan kejahatan dan hakim dapat memerintahkan supaya putusannya diumumkan.

Pemberian hak untuk menuntut ganti rugi kepada pasien tersebut merupakan suatu upaya untuk 
memberikan perlindungan bagi setiap pasien atas suatu akibat yang timbul baik fisik maupun non fisik karena kesalahan atau kelalaian tenaga kesehatan. Perlindungan ini sangat penting karena akibat kelalaian dari dokter tersebut mungkin dapat menyebabkan rasa sakit, luka, atau kerusakan pada tubuh. Dalam menentukan besarnya ganti rugi yang harus dibayarkan, pada dasarnya harus berpegang pada asas bahwa ganti kerugian yang harus dibayarkan sedapat mungkin membuat pihak yang rugi dikembalikan pada kedudukan semula seandainya tidak terjadi kerugian atau dengan kata lain kerugian menempatkan sejauh mungkin orang yang dirugikan dalam dalam kedudukan yang seharusnya andaikata perjanjian dilaksanakan secara baik atau tidak terjadi perbuatan melanggar hukum. Dengan demikian ganti kerugian harus diberikan sesuai dengan kerugian yang sesungguhnya tanpa memperhatikan unsur-unsur yang tidak terkait langsung dengan kerugian itu, seperti kemampuan/kekayaan pihak yang bersangkutan.

\section{KESIMPULAN DAN SARAN}

Karakteristik wewenang praktik tukang gigi bersifat legal apabila sesuai dengan dasar hukum pekerjaan tukang gigi telah diatur oleh pemerintah yaitu Peraturan Menteri Kesehatan Nomor 53/DPK/1/K/1969 dan Peraturan Menteri Kesehatan 339/MENKES/PER/V/1989 tentang Pekerjaan Tukang Gigi. Aturan tersebut mengatur mengenai wewenang, larangan dan perizinan tukang gigi. Pengertian tukang gigi dalam Peraturan Menteri Kesehatan Nomor 339/MENKES/PER/V/1989 adalah mereka yang melakukan pekerjaan di bidang penyembuhan dan pemulihan kesehatan gigi yang tidak mempunyai pendidikan berdasarkan ilmu pengetahuan kedokteran gigi serta tidak memiliki izin menteri kesehatan untuk melakukan pekerjaannya. Permenkes Nomor 339 Tahun 1989 juga mengatur mengenai kewenangan pekerjaan tukang gigi yaitu membuat gigi tiruan lepasan dari akrilik sebagian atau penuh dan memasang gigi tiruan lepasan. Adapun larangan tukang gigi yang diatur dalam Permenkes Nomor 339 Tahun 1989 yaitu melakukan penambalan gigi dengan tambalan apapun, melakukan pembuatan dan pemasangan gigi tiruan cekat/mahkota/tumpatan tuang dan sejenisnya, menggunakan obat-obatan yang berhubungan dengan tambalan gigi baik sementara maupun tetap; melakukan pencabutan gigi, baik dengan suntikan maupun tanpa suntikan, melakukan tindakan-tindakan secara medis termasuk pemberian obat-obatan. Jadi, karakteristik wewenang praktik tukang gigi dianggap ilegal bila melakukan praktek di luar kewenangannya. Pertanggungjawaban hukum tukang gigi apabila melakukan praktik diluar kewenangannya dapat ditinjau dari hukum pidana, perdata, administrasi, dan hukum kesehatan. Tukang gigi dapat didakwa dengan KUHP pasal 359, 360, 361 yaitu barang siapa karena kesalahannya (kealpaannya) menyebabkan orang lain luka, cacat berat, bahkan mati. Selain itu, Undang-Undang Perlindungan Konsumen No.8 tahun 1999 Pasal 4 UU Perlindungan Konsumen mempunyai hak atas kenyamanan, keamanan, dan keselamatan dalam mengkonsumsi barang dan/atau jasa dapat digunakan. Sedangkan dalam Kitab Undang - Undang Hukum Perdata dapat dikenakan Pasal 1365, 1366, dan 1367 tentang perbuatan melanggar hukum, yang 
membawa kerugian kepada seorang lain. Adanya sanksi administrasi seperti teguran tertulis, pencabutan ijin sementara maupun tetap. Dari segi hukum kesehatan Pasal 58 Undang-Undang Nomor 36 tentang Kesehatan yaitu dapat menuntut ganti rugi terhadap penyelenggara kesehatan yang menimbulkan kerugian akibat kesalahan atau kelalaian dalam pelayanan kesehatan yang diterimanya.

Karakteristik wewenang praktik tukang gigi yang ilegal dapat dicegah dengan sosialisasi ke tukang gigi, masyarakat, serta pemerintahan setempat agar lebih berhati-hati serta mematuhi hukum positif di Indonesia. Setelah mengetahui resiko terhadap pelanggaran yang di lakukan oleh tukang gigi tak berizin, seharusnya masyarakat lebih berhati-hati dan diharapkan kesadaran masyarakat dalam memilih pelayanan kesehatan yang terbaik demi kesehatan hidup masing masing. Diharapkan agar pemerintah bersama tenaga kesehatan yang ada dapat mengadakan penyuluhan pada masyarakat tentang apa yang boleh dilakukan oleh tukang gigi dan resikonya. Serta dapat mengupayakan untuk memberikan pelayanan kesehatan gigi dan mulut yang lebih terjangkau kepada masyarakat. Apabila tetap melanggar peraturan perundang-undangan maka tukang gigi dapat dituntut dari hukum positif yang ada di Indonesia. Kurangnya pengawasan dari pemerintah juga berdampak pada banyaknya praktik tukang gigi yang melebihi wewenangnya. Kementrian kesehatan dan dinas kesehatan kabupaten/kota hendaknya lebih disiplin dalam menerapkan berbagai sanksi administrasi misalnya berupa teguran tertulis, pencabutan ijin sementara maupun tetap agar tukang gigi praktik sesuai peraturan perundang-undangan yang berlaku.

\section{DAFTAR RUJUKAN}

Undang-Undang Dasar Negara Republik Indonesia Tahun 1945

Undang-Undang Nomor 36 Tahun 2009 Tentang Kesehatan

Undang-Undang Praktik Kedokteran pasal 36 tahun 2014 tentang tenaga kesehatan

Kitab Undang-Undang Hukum Pidana

Kitab Undang-Undang Hukum Perdata

Peraturan Menteri Kesehatan Nomor 53/DPK/1/K/1969 tentang pendaftaran dan perizinan praktik tukang gigi

Peraturan Menteri Kesehatan No. 339/MENKES/PER/V/1989 tentang pekerjaan tukang gigi

Peraturan Menteri Kesehatan Nomor 1871/Menkes/Per/IX/2011 tentang pencabutan Permenkes no 339 tahun 1989

Peraturan Menteri Kesehatan No. 39 Tahun 2014 tentang pembinaan, pengawasan, perizinan, pekerjaan tukang gigi

Abdulkadir Muhammad, Hukum Perikatan, Alumni, Bandung, 2002, hlm 142.

Andi Hamzah, Kamus Hukum, Ghalia Indonesia, 2005.

Depkes Republik Indonesia. 2007. Kebijakan Obat Tradisional NasionaI. Jakarta : Departemen Kesehatan Republik Indonesia.

M. Sadar, dkk, Hukum Perlindungan Konsumen Indonesia, Akademia, Jakarta, 2012, hal.2-3

Notoatmodjo, S. 2010. Metodologi Penelitian Kesehatan. Jakarta : Rineka Cipta 
Osterberg T, Lundgren M, Emilson CG, Sundh V, Birkhed D, Steen B. 1998. Utilization of dental services in relation to socioeconomic and health factors in the middle-aged and elderly Swedish population. Swedia: Göteborg University.

Philipus M. Hadjon, Tentang Wewenang, Yuridika, No.5-6, (1997), hlm.1.

R. Abdul Djamali dan Lenawati Tedjapermana, Tanggung Jawab Hukum Seorang Dokter Dalam Menangani Pasien, Abardin, Jakarta, 2013, hlm. 128.

Satjipto Rahardjo, Ilmu Hukum, PT. Citra Aditya Bakti, Bandung: 2000, hlm 55

Tengker, F., 1991, Pelayanan Kesehatan dan Pendemokrasian, Bandung : Nova, hlm.15.

Titik Triwulan dan Shinta Febrian, Perlindungan Hukum bagi Pasien, Prestasi Pustaka, Jakarta, 2010, hlm 48.

Wangsarahadja K. Kebutuhan pelayanan kesehatan gigi dan mulut pada masyarakat berpenghasilan rendah. M.I.Kedokteran Gigi;2007:22(30):90-7.

Williams JK, Cook PA, Isaacson KG, Thom AR. Alat-alat ortodonsi cekat. Jakarta: EGC;2000. h. 1-2

Wirjono Prodjodikoro, Perbuatan Melawan Hukum, Mandar Maju, Bandung, 2000, hlm 2.

Yuningsih, Rahmi, 2012. Pengobatan Tradisional di Unit Pelayanan Kesehatan. Info Singkat Kesejahteraan Sosial. Vol. IV, No. 05/I/P3DI/Maret/2012. 